Sandy Zinn*, Christine Stilwell and Ruth Hoskins

\title{
Information Literacy Education in the South African Classroom: Reflections from Teachers' Journals in the Western Cape Province
}

DOI 10.1515/libri-2015-0102

Received November 7, 2015; accepted December 22, 2015

\begin{abstract}
This qualitative study reports on teachers in the Western Cape as they attempt to embed information literacy in their classrooms. It explores how teachers come to understand information literacy and the extent to which they change their beliefs about guiding research projects in a more concerted way. The research questions were: (1) how do teachers understand information literacy education? (2) how do teachers make their information literacy explicit in the classroom? and (3) at what level are teachers' web knowledge and skills? The teachers, who were part of an information literacy education course, formed a purposive sample. The data for this study emanated from solicited, reflective journals which participants kept over a period of eight to 10 weeks. Information seeking and use theory and an inquiry-based approach to learning frame this research. Motivation for the study is rooted in a curriculum which embodies information literacy characteristics. Traditionally, information literacy has been the domain of the school librarian. Only $16.82 \%$ of South African schools have a stocked library. With so few school libraries and no official position in schools for a qualified school librarian, the onus for teaching information literacy thus rests on the teacher. This article provides the context for South African education and a review of the information literacy literature with an emphasis on South Africa and teachers' information literacy. The results show that, despite many obstacles in these teachers' paths, they express a fairly sound understanding of information literacy education by the end of the journaling exercise. However, fewer teachers can competently mediate information literacy in the
\end{abstract}

\footnotetext{
*Corresponding author: Sandy Zinn, Department of Library and Information Science, University of the Western Cape, Cape Town, South Africa, E-mail: sandyzinn@gmail.com

http://orcid.org/0000-0002-0212-0036

Christine Stilwell, Ruth Hoskins, Department of Information

Studies, University of Kwazulu-Natal, Pietermaritzburg, South Africa
}

classroom. One of the major barriers to information literacy is the teachers' slow adoption of the World Wide Web. Recommendations for further study include examining teacher education programmes for their inclusion of information literacy education; for awareness of plagiarism and the ethics of information use in the school environment; and the effect of information and communication technology on learners' information literacy.

Keywords: information literacy, inquiry-based learning, information seeking, South Africa, teachers

\section{Introduction and Motivation for the Study}

Traditionally, information literacy has been the domain of the school librarian. In South Africa, with its dearth of school libraries, school librarians are scarce. The ability to find, organize and evaluate information for decisionmaking and problem solving is a life skill and therefore desirable for all learners. These information literacy skills can be taught generically across the curriculum (e. g., by a school librarian) and specifically within the context of a subject (by the teacher). Teachers should be role models of information literacy and are expected to mentor and guide learners through the process of learning. The question thus arises: is information literacy being taught at South African schools and are teachers equipped to facilitate it?

The National Curriculum Statement (NCS) Grade R-12, also referred to as the Curriculum and Assessment Policy Statement or CAPS, which stipulates policy on curriculum and assessment in the schooling sector, was phased in from January 2012. The aims, purpose and principles of this NCS (South Africa 2011a) embody very similar characteristics to the previous NCS (South Africa 2002). The learner who emerges from immersion in the curriculum is envisaged as someone who, amongst other things, thinks critically, is able to apply learning, uses information from a wide range of resources to build new knowledge, and 
communicates intelligently and intelligibly. These characteristics of a successful learner are manifest in the attributes collect, organize, analyse and critically evaluate information; identify and solve problems and make decisions using critical and creative thinking; and communicate effectively using visual, symbolic or language skills in various modes. These three learner traits best embody the concept "information literacy" in the South African curriculum. Each subject has outcome statements epitomizing information literacy. One purpose of the curriculum remains to equip learners with the "knowledge, skills and values necessary for self-fulfillment, and meaningful participation in society as citizens of a free country" (South Africa 2011a, 4). Some of the principles are active learning as opposed to rote learning, instilling a human rights culture in education that incorporates inclusivity, environmental and social justice, and providing a quality education commensurate with that of other countries.

In 2009, the Minister of Education, Angela Motshekga, appointed a panel of experts to look into the challenges related to the implementation of the 2002 NCS, a revision of the former 1997 curriculum. The ongoing public disquiet and criticism of the 2002 curriculum led to the review. In the review, research projects and assignments were criticized for being "superficial" in nature and the tasks lacking in "educational rigor" (South Africa 2009). Research projects are often mentioned in the research literature as a channel to information literacy (Hart 1999; Williams and Wavell 2006; Asselin, Kymes, and Lam 2007; Herring 2007) but learners in rural and poorer communities were disadvantaged because they lacked access to information for these projects. Often parents completed the projects for their children or projects were simply plagiarized. Teachers lacked expertise in teaching learners how to conduct research projects. Projects were often poorly set with little guidance or scaffolding. Projects also required access to resources such as those in libraries and on the Internet, both of which are scarce in schools (South Africa 2009).

In their final recommendation, the panel of experts acknowledged that research projects do develop crucial skills of retrieving information, solving problems and thinking critically and creatively. They advised that there should be no more than one project per annum per subject. Further the Department of Education should provide examples of projects as well as indicate how these projects should be supported (South Africa 2009, 65) or broken up into learning chunks with a tool provided for dealing with each chunk.
Additional motivation for investigating information literacy at the school level, stems from tertiary institutions' confrontation with students' lack of information literacy. More and more universities are realizing that undergraduate students do not come prepared for tertiary level studies and do not absorb information literacy by “osmosis” (Walker 2001). King's (2007) study, of University of the Western Cape's (UWC) undergraduate students' lack of readiness for academic learning, adds weight to Walker's views. In recent years most tertiary institutions in South Africa have begun offering some information literacy intervention (such as web-based e-learning modules; credit-based courses) for first year students (De Jager, Nassimbeni, and Underwood 2007, 142).

While ensuring that students leave university information literate is an accomplishment, training them in how to foster and inculcate information literacy in their learners (if they become teachers) necessitates a grounding in methodologies such as inquiry-based learning and resource-based learning, both of which complement information literacy. Olën (1994) identified the omission of use of library media centres and resource-based learning in the initial training of South African teachers. Asselin (2003) conducted a study of pre-service teacher training in Canada and also found that the value of the school library programme and school librarians in the curriculum was overlooked. The cohort of teachers presently teaching in our schools seems to have great difficulty in knowing how to approach inquiry-based learning, which is learnercentred and resource-based. Evidence gleaned from teachers' portfolios of a course in information literacy education (Zinn 2008) illustrates that teachers were illprepared for and lacked confidence in supporting learners during the information literacy process. A Western Cape Education Department report (Western Cape 2007) on the quality of teaching and learning and educator development demonstrates clearly teachers' inability to use resources for learning.

The 2009 curriculum review focused on several aspects of the implementation of the NCS, one of which was the problems related to research projects. Perhaps, given the brief, the solutions offered by the review committee (reducing the number of projects and offering exemplars) do not address the underlying pedagogy of research projects. Do teachers understand the learning that takes place when children are undertaking projects? It is evident from the review that teachers have a superficial knowledge of information literacy education. There seems to be a gap in the research on teachers' interpretation of information 
literacy. Most research on information literacy focuses on librarians, information professionals and the library environment. The literature focusing specifically on teachers' competency in information literacy education appears limited. Some South African studies are those of Zinn (1997) and Hart $(1999,2005)$, and international studies are those of Moore (1998); Henri (2001); Slyfield (2001); Merchant and Hepworth (2002); Williams and Wavell (2006); and Probert (2009).

This article reports on a study of teachers in the Western Cape as they attempt to embed information literacy in their classrooms. It explores how teachers come to understand information literacy and the extent to which they change their beliefs about guiding research projects in a more concerted way, as expressed through their journals.

\section{Research Questions}

The latest NCS (South Africa 2011a), like its 2002 predecessor, emphasizes active learning not rote learning. Active learning requires interaction with a wide variety of resources (print or digital) for information-based assignments. The ability to access and use resources (beyond the textbook) requires learners to have knowledge of different resources, information handling skills and positive attitudes to information seeking such as being persistent, attending to detail and interrogating information and sources rather than accepting them at face value (Kuhlthau, Maniotes, and Caspari 2007. The literature indicates that the school librarian is the educator most often identified as tasked with teaching generic information skills. South African public schools without stocked libraries amount to $83.18 \%$ of the total (South Africa 2014a). Dependency on school librarians in general to impart information literacy is therefore out of the question.

Hart (2005), in her study of the readiness of public librarians to teach information literacy, comes to the conclusion that they are not quite equipped for that role. The onus thus rests on the classroom teacher. This study sought to answer the following questions:

1. How do teachers understand information literacy and information literacy education?

2. How do teachers make their information literacy explicit in the classroom?

3. At what level are teachers' web knowledge and skills?

The value of this qualitative research lies in the illuminative insights it offers about the phenomenon of information literacy education as perceived through teachers' journals in the context of the Western Cape Province, South Africa.

\section{Literature Review}

Firstly, the education context in South Africa is addressed. The literature review on information literacy education that follows focuses on selected studies in the literature with an emphasis on South African studies and a few international studies.

\section{The South African Education Context}

The discrepancies inherited as a result of apartheid that are apparent in school infrastructure, access to human and learning resources, access to quality education and differentiated funding for schools along racial lines, have been well documented in the literature (Jansen and Taylor 2003; Fiske and Ladd 2004; Taylor, Fleisch, and Schindler 2008). The state of education in South Africa today is still seemingly unhealthy. While the popular focus is on the Grade 12 end of schooling results, the dismal state of learning and teaching in the lower grades has been exposed in the Annual National Assessment (ANA) results (South Africa 2011b, 2014b). These results served to confirm earlier international studies which South African learners participated in such as the Trends in International Mathematics and Science Study (TIMSS) 2003 in which Grade 8 learners were tested in mathematics and science; the Progress in International Reading Literacy Study (PIRLS) 2005 in which Grade 5s were tested for literacy; and the Southern and Eastern African Consortium for Monitoring Educational Quality (SAQMEQ) studies of 2001 and 2007 in which Grade 6s were tested in language and mathematics (South Africa 2011b, 10; Equal Education 2011, 5). These results showed that South African children, especially those in rural and poor communities, perform well below the expected levels (South Africa 2011b, 30). The state expenditure on education is $20 \%$, the largest single item in the national budget. Yet, South African children have performed consistently worse than those from countries with much lower Gross Domestic Products (Taylor 2007; Equal Education 2011, 5).

Since the introduction of the new curriculum in 1997, there have been a number of South African studies which sought to expose and explain the education conundrum - that is, besides the annual literacy 
and numeracy studies. The various studies point repeatedly to the same or similar challenges in education in South Africa:

- If you live in a poor, rural community your chances of succeeding at school are low (Fiske and Ladd 2004; South African Human Rights Commission (SAHRC) 2006, 18; Taylor 2007, 4; Taylor, Fleisch, and Schindler 2008, 41; Spaull 2012)

- The quality of education learners' experience is unequal, resulting in disadvantage based on social class and race (Fiske and Ladd 2004; SAHRC 2006, 39)

- The language of learning in the classroom needs to be bolstered in the home environment but this is not happening. Children are not learning to read even in their home language (Taylor 2007, 4; Taylor, Fleisch, and Schindler 2008, 43)

- Teachers' knowledge of their subject is generally inadequate (Taylor, Fleisch, and Schindler 2008, 50; Hoardley and Ward 2009, 59-60)

It is heartening to note that different drivers in education are putting school library provision back on the agenda. The SAHRC (2006, 42), as part of infrastructure recommendations, proposed a library in each school, along with toilets, electricity, water and perimeter fences. The LIS Transformation Charter $(2014,48)$ argues for school library development based on the underlying principles that (1) the curriculum requires access to a variety of wellmanaged learning resources; (2) global competitiveness demands that learners exiting schooling be information literate (this includes information and communication technology (ICT) literacy or fluency). Information literacy is the traditional domain of school librarians, implying that school libraries are more than a "place." The school library is more a learning commons; (3) school library services develop literacy because they focus on encouraging a love for reading; and (4) school LIS is a "force for social cohesion." The library provides a safe place for learners after hours to interact, and explore the "wider world."

In the Western Cape the most common home languages are Afrikaans (55.3\%), isiXhosa (23.7\%), and English (19.3\%) (Statistics South Africa 2011). In the Western Cape in 2014, there were 1,440 public ordinary schools of which 431 schools or $29.93 \%$ had a stocked library, but no statistics are available for the number of librarians (South Africa 2014a, 3). In the Western Cape, there were 1,026,744 learners in public ordinary schools and 32,237 educators, this is a ratio of 32 learners per educator (South Africa 2014c, 1).

\section{Understanding Information Literacy in the Information Age}

Information literacy has been variously defined by, among others, the Association of College and Research Libraries (ACRL) (2002), Kuhlthau (2004), and the Library and Information Association of South Africa (LIASA) (2004). Essentially, information literacy is a broad concept that embraces information skills, ICT skills, and library skills along with problem-solving and cognitive skills, as well as attitudes and values, that enable learners to function effectively in the information landscape (Ministry of Education and National Library of New Zealand in Probert 2009).

Advances in technology and ICTs specifically have enabled an unprecedented growth in information. The ability to access vast amounts of information is of little value unless individuals can sift the garbage from the "gold" i. e., select and use the most pertinent information for knowledge creation. ICTs have therefore precipitated information literacy (McKenzie 1999; Bruce 2002; Moore 2002).

\section{A Review of the Information Literacy Literature with an Emphasis on South Africa and Teachers' Information Literacy}

The Baxen and Green study (1998) set out to explore how teachers in South African primary schools use learning support material (LSM). The findings overlap with information literacy education studies in several important respects: The teachers in this study assumed that learners could use the learning material like charts without mediation (Baxen and Green 1998, 59). Teachers assumed that providing access was enough. Williams and Wavell (2006) reported a similar finding with their teachers in the United Kingdom. Teachers had not given thought to the complex skills and knowledge required for accessing information within different texts.

On the other hand, the teachers were effectively using resource-based teaching methods but not resource-based learning methods, as they were not allowing learners to interact with resources. Teachers found it difficult to "let go" and allow learners to find out for themselves from resources. Teachers were emphasizing the "right" answers when alternative forms of questioning and answering could have been adopted. In the Merchant and Hepworth (2002), and Henri (2001) studies, the quest for the "right answer" or single solution underlies a superficial approach to learning.

Teachers viewed knowledge as "external, fixed and beyond their control" (Baxen and Green 1998, 84). The idea of knowledge as a social construct and constantly 
changing was alien to teachers. They were not confident and competent to implement learner-centred approaches. The authors recommend a need for in-service training to improve teachers' knowledge of the subjects they teach. Teachers' poor knowledge base in the subjects they teach has been repeatedly documented by South African educational researchers such as Morrow (2007), Taylor (2007, 2010), and Hoadley and Ward (2008).

Hart (1999) conducted a case study of a Grade 7 class as they undertook projects. This was an urban primary school in an indigent coloured neighbourhood. Her curiosity centred on how teachers in disadvantaged communities, lacking in resources like libraries and laboratories, undertake research project work. What became clear to Hart was that teachers' attitudes to their students ultimately determine what they practise in class. From interviews with teachers it became apparent that teachers were not convinced of the discovery approach to projects as they were not in control of the class. The teachers had evolved to the resource-based teaching level not the resource-based learning level. They were more convinced of the need for setting up a teachers' resource centre with a variety of textbooks for pretty worksheets (lots of pictures) than a library for the students to interact with a variety of resources. As in the Baxen and Green $(1998,81)$ study of LSM use in primary schools, teachers were not comfortable with allowing students to interact with resources.

Czerniewicz (1999) produced a report on information literacy in the Western Cape at a time when the first national policy framework for school library standards of 1998 was tabled and which embodied the teaching of information literacy as one of the roles of the teacherlibrarian. The report provided the first baseline study which featured ICTs as a part of information literacy in South Africa. Future references to information literacy would arise most strongly within the ICT field rather than purely in school education. Boekhorst and Britz (2004) are of the same mind when they argue in their comparison of the Dutch and South African education systems that information literacy has been captured most convincingly in the ICT curriculum. In the White paper on e-education (South Africa 2004) information literacy has infiltrated the language of ICT in transforming ICT literacy into an ICT capability concept or what is internationally referred to as information fluency.

Hart's (2005) study questioned to what extent South African (the Mpumalanga province in particular) public libraries and librarians were ready to build a sustainable information literacy education programme. The need for
Hart's study in 2005 and the current study is based on the reality that in South Africa only $7.7 \%$ of schools have a stocked, fully functioning library (Equal Education 2011) and a curriculum that demands project work (South Africa 2009). The respondents saw information literacy as equivalent to book education which focuses on sources of information. They view information as a source, and do not view it cognitively. The conclusion of the study conveys the strong impression that public libraries are not yet ready for the information literacy education role.

In Hart's (2011) study of dual-use school community libraries in a rural area of South Africa, she identified that, despite being physically located on the school premises, teachers did not collaborate with librarians on projects. It is clear that the educators do not understand the mission of a school library and do not exploit the potential collaboration between the two professions, a view echoed in Maepa and Mhinga's study (2003).

There are few international studies concentrating on teachers' information literacy capabilities without the presence of professional, fulltime school librarians. Studies emerging from New Zealand schools, where no publicly funded school librarian posts exist, question the assumption that teachers know how to mediate information literacy. In New Zealand, researchers Moore (1998), Slyfield (2001) and Probert (2009) question whether teachers are making information literacy explicit. Common findings amongst the three authors are that teachers endorse information skills as the route to lifelong learning, but they are not "operationalising" this endorsement in classroom activities.

Henri's (2001) study, amongst Hong Kong teachers in an information literacy education class, established that teachers had more confidence in carrying out information tasks using older rather than newer technologies. There were teachers who thought that there was a magical single source which would provide the answer - "the silver bullet." Few teachers understood that the task at hand was about gathering evidence to support an argument rather than a single solution to be found (Henri 2001, 125).

In the United Kingdom, the Merchant and Hepworth (2002) study of teachers' abilities to teach information literacy, it became evident that despite the teachers themselves being information literate, they lacked a conscious understanding of the skills the concept comprises. In 2006 in the United Kingdom, Williams and Wavell studied teachers' experiences of information literacy in the classroom. Some of the results of their study include: 
teachers focusing on the finding of information because it is a controllable activity such as sending students to the library; teachers seeing projects as naturally motivating and easy to accomplish; teachers not knowing how to teach students to link prior knowledge to new knowledge; and teachers admitting that students needed a variety of skills to execute a research project, but it was not their responsibility to teach it. An exam oriented curriculum left little time to devote to projects.

The current study is framed by information seeking and use theory (Kuhlthau 2004) and an inquiry-based approach to learning (Kuhlthau, Maniotes, and Caspari 2007. In Kuhlthau's (2004) approach, uncertainty, doubt or a gap in information propels the individual to seek information. The individual traverses six stages in the information search process (ISP) which not only includes the intellectual (cognitive) and actions (physical) but also the affective (emotional) aspect. The ISP approach to information behaviour embodies a holistic approach to learning through thoughts, actions and feelings. As the current empirical study focuses not only on teachers' own information literacy, but also on their ability to mediate information literacy in the classroom, it presupposes that teachers are metacognitively aware of how learning, especially deep learning, takes place. An inquiry-based approach to learning and teaching "emphasizes thinking about information and using information within a problem-solving perspective and that integrates the knowledge of tools, sources, and search strategies within the teaching of thinking and problem solving" (International Federation of Library Associations and Institutions 2015, 54).

\section{Methodology}

This study forms part of a larger, mainly qualitative study investigating teachers' competency in information literacy education. The investigation incorporated several data collection tools such as interviews, mind maps, observation, journals and project artefacts. This report focuses on one data collection instrument, the journal. The context of the study is an advanced certificate in education school librarianship programme course: information literacy education. Some of the teachers in the course volunteered to participate in the study forming a purposive sample of 29 participants. These teachers were not qualified teacher-librarians. They were all studying towards an advanced certificate in education in school librarianship. The information literacy education course intervention was intentional and was meant to establish whether or not there are any shifts in teachers' initial beliefs, attitudes and actions during and after the course. This is not necessarily an anomaly. Henri (2001) used both teachers and unqualified teacher-librarians in his study of their information literacy abilities. There was no reported difference between the results of the two groups.

All the participants were fulltime classroom or subject teachers. The average age of the participants was 45 years and the majority, $93 \%$ or 27 participants, were female. There were six high school teachers, 22 primary school teachers and one subject advisor. Home languages were Afrikaans (17 participants), Xhosa (six participants), and English (six participants). Nine participants taught in urban areas and the rest taught in 11 schools in rural villages and seven schools in rural towns. About $71 \%$ of these schools fall mainly in quintiles one and two, designated the lowest economic levels for schools in the Western Cape.

All the schools save three in rural villages had computer laboratories with between 20 and 25 workstations in each laboratory. All the laboratories had some Internet access ranging from three computers to all computers. At the start of the course, 19 teachers indicated that they had computers at home but only eight teachers had Internet access at home. One school in an urban area has a fully functioning library the rest had either a collection (store of mainly books, no librarian) or nothing at all. Twelve schools $(41 \%)$ had a public library further than $3 \mathrm{~km}$ away. All the teachers were members of the Western Cape Education Library Service and/or the district resource centre, where they could borrow block loans of books for a month at a time.

A major part of the course assessment was teachers' showing that they could teach information literacy by way of a research project with learners. Teachers participating in the study were required to keep a written journal in which they regularly described their reflections, new learning, frustrations, moments of joy and other details experienced in the course sessions as well as whilst conducting information literacy with learners. These solicited dairies were kept at the behest of the researchers and participants knew that they were going to be viewed "publicly" (Meth 2003, 196). Atlas.ti was used to facilitate the conceptual content analysis of the journals.

One drawback was that the writing in the journals might reflect what the researchers wanted to hear and therefore might exclude knowledge that the writer felt was important. Both Hubbs and Brand $(2005,66)$ and Eidse and Turner $(2014,244)$ express a similar concern in their studies that participants might decide to "selfedit" to satisfy the researcher. Nevertheless, journal keeping promotes participant involvement and engagement in 
the research process and is regarded as a useful qualitative research method (Meth 2003, 195). There are several advantages to journal writing for both the writer and the reader: the writer's points of view and priorities are divulged; diaries offer "temporal insights" whereas other methods such as interviews and questionnaires are usually once-off affairs; diary writing can be empowering; diary writing can be used as a reflective tool; and diaries can be used as part of a multiple method approach (Spalding and Wilson 2002, 1394, 1396; Meth 2003, 196, 198, 200, 201).

Participants kept a longitudinal, reflective journal over a period of between eight and 10 weeks. The strength of protracted journal writing lies in its "break in logic" between entries. Meth $(2003,198)$ claims this probably reflects more precisely the varied thoughts and feelings in human awareness. In interviews and questionnaires, a particular line of response can be adopted by both respondent and interviewer. Interviews can easily skew responses and send subsequent responses off on a particular tangent. At the same time, Hayman, Wilkes, and Jackson $(2012,30)$ warn that the lengthy period of journal keeping may result in reduced participation as the process may be viewed as a burden.

Two assumptions were made: (1) that all participants who happened to be teachers understood what journal writing was; and (2) that all participants understood what reflection was. These assumptions were based on knowledge of curriculum in-service training in which teachers were introduced to the concept of journal keeping, and it is one of a range of assessment tools that teachers can use. Similarly, with reflective thinking, teachers are constantly involved in in-service professional development and continuing education; the assumption was that the concept was not new to them.

\section{Findings and Discussion}

The journal as a tool for reflection and assessment was new to most (69\% or 20) participants on the course. This revelation was a surprise as one of the forms of assessment in CAPS (and even in previous national curricula) is keeping a journal (South Africa 2011a). Some teachers wrote extensively and intensively while others wrote sporadically and sketchily. Some teachers focused on the stipulated criteria, others digressed and wrote completely off the point.

The participants in the study will be referred to by number as "participant \#” or "teacher \#." The findings will be discussed according to the research questions.

\section{How Do Teachers Understand Information Literacy Education?}

In their journals, teachers had to reflect on their new learning in the information literacy education course. In their journals they come to terms with their own information literacy inadequacies and new awareness regarding the teaching of information literacy.

Right at the start of the course teachers' fundamental beliefs about learning and teaching are shaken. Teacher \#9 realises that she herself needs to be information literate first before she can guide her learners (students). She acknowledges that she lacks the "right skills." In viewing the information literacy self-efficacy of the same cohort of teachers, their (the teachers') scores were low for writing a research paper, creating a bibliography and citing sources, and for presenting findings in an appropriate way (Zinn 2013). The majority of teachers $(76 \%)$ in the study were primary school teachers who attended teachers' colleges where carrying out research and writing research papers did not form part of the training.

Teacher \#10 makes the point in her journal that sometimes she forgets that her learners do not have the domain-specific knowledge that she has about the subjects she teaches. Her challenge is to understand the anxiety of her learners when giving them an assignment or the feelings they might have when handing in a project. Merchant and Hepworth (2002) and Williams and Wavell (2006) allude to teachers' views of projects as easy whereas learners experience the opposite.

Participant \#10 reflects further on the cognitive skills in the research process. She says:

Today we start with the cognitive skills and I start to think which of these skills I take for granted in my class. We do a lot of prior knowledge and from now on I think we should focus on keywords, mind maps and the W-questions (where, why, when, what). I must look at how I am going to teach this.

As the teachers in the three New Zealand studies (Moore 1998; Slyfield 2001; Probert 2009) realise, information literacy education does not come naturally, teachers need to be taught too.

Participant \#9 deliberates on the notion of the information search process as a triad of thoughts, actions and emotions. For 10 years already she has experienced in her own classroom that learning is not only about the cognitive: "To get the learners active we need a stimulating and inspiring, motivational and comfortable environment. If the environment is not healthy or favourable, learning does not take place effectively.” Having been 
exposed to Kuhlthau's (2004) ISP model of information literacy, she thoughtfully states:

To me the learners are unique and not everyone changes in the same way as the other. Because of that we need to address the learners' needs differently. I experienced it in the group work activity (during the course). In the classroom it is not always possible to do that because of the huge classes, time and lack of information resources.

Having endorsed Kuhlthau's approach, she immediately recognises the challenges in her own environment. Her school, in a rural village, has classes of $45+$ learners per classroom; there is no school library and no computer laboratory, conditions brought to light by the research of Fiske and Ladd (2004), the South African Human Rights Commission (2006), Taylor (2007), and Taylor, Fleisch, and Schindler (2008).

\section{Designing Engaging, Challenging Research Projects}

Using Loertscher's (1996) ideas on "turning assignments into more engaging problems," the teachers in the course had to design research projects which were engaging and challenging and which could not be simply copied and pasted. This exercise was partially in answer to the question of how to prevent plagiarism and as a preparation for the actual research project with their respective classes. Having accepted that one way of preventing plagiarism is to design research assignments in a more thoughtful way, when confronted with the exercise, participants realised that the task was harder than they had expected. It appears that, while the ministerial panel of experts advocated for a continuation of projects (South Africa 2009), the in-service training of teachers fell short of the actual management of projects. There are participants in the study who express utter frustration with the exercise (\#24; \#29) but with practice succeed in the end. Then there are those participants who see it as a healthy alternative to the worksheet syndrome. Worksheets often consist of sentences copied verbatim from the textbook with gaps which learners fill by spotting answers in the textbook (Hart 1999). While $65 \%$ of participants manage to create engaging, thoughtful research topics, about 10 participants (35\%) do not succeed with this exercise in the end.

\section{Planning the Research Assignment}

In planning their research assignments, some teachers demonstrated their information literacy awareness through consciously addressing a variety of intelligences (after Howard Gardner's (1999) multiple intelligences), such as bodily/kinesthetic and spatial intelligence. Before the course intervention, many teachers had not known how to motivate learners in projects until being challenged by Small and Arnone's (2000) Motivational Style Quotient (MSQ) in which teachers had to rate themselves in terms of motivation when giving learners a research assignment. Many teachers were surprised by their low rating and realised that learners needed much more guidance and motivation from them. The MSQ was another strategy in raising the awareness of teachers about the non-cognitive aspects of information literacy as per Kuhlthau's ISP (2004).

The lucid voice of teacher \#1 epitomizes the findings of Merchant and Hepworth (2002) and Williams and Wavell (2006) in which teachers do not consider the cognitive difficulties of confronting texts. She writes:

I like giving interesting assignments, but I have failed in the following through of it. I realise now that I expected way too much of my Grade 7 social science learners. Maybe that is why more than half did not hand in their assignments. I have expected them to read many different books (that I brought to school via block loan) and to synthesize the information without giving them a framework. I take it for granted that they know how to sift and collate information from different sources. I thought they could do it because they enjoyed reading the books and researching the information. They must have been totally overwhelmed!

She continues in a way that reveals her feelings and critical insight:

\begin{abstract}
I feel awful now. I did ask them if they had been taught how to take notes and they said, no. So I gave them a brief overview of it, but I did not do enough. I assumed because they were quiet in class and reading the books that they were managing ok. Obviously they were not. I should have kept tabs on them and assessed them on an ongoing basis. They have never had similar assignments from other teachers. All that is expected of them is to use textbooks and fill in forms. That makes it easier to mark, but what is the point of it? - The learner has the required number of pieces of work in their portfolios - but a lot of it is meaningless, "busy" work.
\end{abstract}

\section{The World Wide Web and Information Literacy}

One of the greatest challenges for the participants was working on computers and using the Internet. The teachers were much more comfortable with printed texts or "old technology" a finding similar to Henri's study (2001). The question of the teachers' web literacy will be touched on in more detail later again, but their inexperience with the hardware and basic programmes such as MSWord, as 
well as using the Internet put them at a distinct disadvantage in this information age. In rating their own information literacy self-efficacy before the course intervention, the same participants scored themselves low in determining the authority, currency and reliability of web sources (Zinn 2013). The participants had used computers and the Internet for a previous school librarianship course, but seemed initially inept at transferring skills learned from one course to another. The ability to transfer knowledge and skills is an information literacy trait.

\section{Attitudes towards Plagiarism}

The ethics of plagiarism do not seem to be part of in-service teacher training. "Most teachers are guilty of committing plagiarism without thinking they are doing wrong," according to participant \#18. Not one of the study participants on the course was aware of an ethics policy at his/her respective school. After the course session dealing with plagiarism, about $55 \%$ of participants responded with comments in their journals. Participant \#17 had a guilty conscience because she never gave a thought to the amount of effort authors put into creating a text. She was one of the few participants who viewed plagiarism in terms of the wider values in society regarding the way information is used and viewed as opposed to the narrow concept of simply avoiding plagiarism (Williams and Wavell 2006, 208). Unintended plagiarism comments relate to ignorance of how to cite and reference web-based sources. Yet, even after participants were taught how to cite from the web, awareness was not sufficient to persuade them to adopt the practice of acknowledging their sources. Despite a bibliography template being compiled and available for their convenience, not many participants used it. Perhaps there were not enough enabling influences or influencers to convince them to change.

\section{How Did the Teachers Make Their Information Literacy Explicit in the Classroom?}

The teachers in the study were expected to "mediate" information literacy rather than "teach" information literacy, where to teach is too often associated with "telling" or "instructing." They were encouraged to use an inquiry model such as the Alberta model as a scaffold for teaching information inquiry, as each phase of this process model offers skills and strategies that are required to be explicitly taught with examples of application in different subjects (Alberta Learning 2004, 8). Teachers had to explicitly draw learners' attention to how they were learning and thinking (Kuhlthau, Maniotes, and Caspari 2007).

The participants demonstrated their information literacy explicitly in different ways. Teacher \#21's moment of clarity is captured in his journal as "learners need to be explicitly taught how to 'grapple with texts', it does not come naturally to most learners." Teacher \#9 refers to her moment of "revelation" after having done "some selfexamination" in recognizing that she is "doing all the discovering for learners." "I need to allow them to be more independent." Baxen and Green (1998) and Hart (1999) refer to teachers who do not like to lose control in the classroom and therefore steer away from resourcebased learning.

One thread running through the journals is that planning and preparation for the research project took time and effort. Participant \#8 takes two weeks to plan for her Grade 2 project. At first "sceptical" that her learners could do a research project, she relents. She contacts the local public library that assists her with information resources. She searches the web for suitable information and consults the Encarta encyclopaedia and a South African encyclopaedia. She informs the parents about the project as this is the first time learners are doing a project and using a library. Planning, grappling with uncertainty, and managing time are all metacognitive characteristics of an information literate individual (Alberta Learning 2004).

Several participants (\#1; \#4; \#5; \#8; \#28) explicitly mention contacting the public library to inform them of the impending project to which the public library responds very warmly. It is generally uncommon for teachers to have such a good working relationship with the local public library (Hart 2011; Maepa and Mhinga 2003). Participants \#7 and \#21 bring resources into the classroom and participants \#1 and \#20 use experts as information resources. Participants on the whole consulted library books, used expert people and the Internet for their research projects. A positive attitude towards finding and using a variety of information sources comes across quite strongly in the journals.

Part of their newfound confidence in mediating information literacy derives from the skills they explicitly mention that they teach. These include exploring information on the web $(\mathrm{N}=7)$; note-making $(\mathrm{N}=6)$; reading strategies: reading for information, sorting and sifting information $(\mathrm{N}=5)$; using the Dewey Decimal Classification system to find information in a library $(\mathrm{N}=4)$; brainstorming $(\mathrm{N}=3)$; creating a bibliography $(\mathrm{N}=3)$; using prior knowledge 
$(\mathrm{N}=3)$; identifying keywords and mind mapping $(\mathrm{N}=2)$; drawing up interview questions $(\mathrm{N}=2)$; dictionary skills $(\mathrm{N}=2)$; and paragraph writing $(\mathrm{N}=2)$.

Participants report that they are motivating the learners more, for example, by reading stories and singing songs with older learners, an unexpected activity (\#17); and by providing enough time for learners to absorb the new approach and finish successfully (\#19). Williams and Wavell $(2006,208)$ found in their study that, for lifelong learning teachers need to give time for reflection, development of cognitive, higher order thinking skills, and inculcation of behaviour that is questioning, with a healthy dose of skepticism, and a desire to create new knowledge. Likewise, the Small and Arnone (2000) motivating techniques endorse time to pause and think (reflect).

Teachers report that the learners relish the effect of making information literacy explicit. They enjoy reading the collections of library books, visits to either the school or public library, and they are particularly excited to access the Internet. Participant \#16 is of the opinion that her learners' self-esteem has improved. It also appears that more learners complete a successful project than before (\#1; \#5; \#9; \#29).

In conclusion, participants employed innovative features in their research projects which identify them as risk takers and change agents in their own right. Participant \#8 videotaped her entire project so that she could show her learners, the parents and her colleagues. She went to extraordinary lengths to capture her changes. Participant \#1 introduced, in her words, "ground-breaking" changes by inviting experts from the community to view the presentations and assess the learners' projects. Grade 3 learners in participant \#5's class made Mother's Day gifts which they sold to raise funds for the upcoming school library. While these methods may not seem very novel to the seasoned mediator, these teachers are indeed pioneers at their schools.

\section{At What Level Are Teachers' Web Knowledge and Skills?}

At the start of the information literacy education course, the researchers presumed that the teachers, having completed a previous school librarianship course dealing with information sources, would be familiar with computers and the Internet. For the information literacy education course, the teachers had to find five websites for each of their eight school subjects and to annotate them.

Only three schools did not have a computer laboratory. All the laboratories had some Internet access ranging from three computers to all computers having access. Eight teachers had Internet access at home and 19 had computers at home. Of the eight teachers with Internet access at home, only three went online on a daily basis. Twelve teachers used computers every day, 9 once per week and eight about three times per week. Most teachers who used computers on a daily basis taught either Grades 4-6 (five teachers) or Grades 7-12 (six teachers). There was no correlation between urban teachers and either increased computer or Internet access.

The majority of teachers struggled not only with Internet searching but also with computer literacy. Participant \#29 relates how she thought she had copied and pasted Websites only to end up with a blank document. Teachers' anxiety and worry about their lack of computer and Internet literacy were evident in their journals. They used phrases such as "loathed going to the computer laboratory" (\#24) and calling themselves "Internet illiterate" (\#19). There were at least five selfconfessed technophiles who assisted the slower teachers. Participant \#1, one of the participants who was Internet literate to begin with, made the keen observation that not much is available in Afrikaans, the home language of her learners, an observation supported in the literature by Czerniewicz and Brown (2005).

The same cohort of participants in a questionnaire before the course, who sought to establish their information literacy self-efficacy, scored themselves low on the item "determine the authoritativeness, currency and reliability of the information sources" particularly in evaluating web sources (Zinn 2013). This evidence confirmed the teachers' poor ICT abilities at the beginning of the course.

To assist the teachers, a database called Weblinks Research, an Australian database with African input from a South African agent, was introduced. It is organized by subject and grade level as well as by teacher and learner resources. The teachers started to enjoy the possibilities of the web now that they had access to selected websites. The participants had a taste of what it was like to search for information without guidance. This exercise was to demonstrate to them that they should never simply send learners to "surf the internet" - it is too daunting, especially at primary school level.

Another exercise to teach educators about the complexity of reading and understanding websites was to have them evaluate websites. They record this experience in their journals as "dreadful" (\#17); "terrible" (\#11); "frustrating" (\#3); "difficult" (\#14; \#18; \#29); "not easy" (\#10). The negative response had much to do with their inexperience of the Internet, the fact that English is not the home language for most participants but is the 
language of most websites. In another example, participants were referred to an educational website, Zapato. net, set up to intentionally mislead and test users' knowledge and gullibility. Some of the content included topics such as "buying dehydrated water," "wearing an aluminum deflector beanie as a low-cost solution to combating mind-control," or trying to save an imaginary country called the "Republic of Cascadia." Many participants could not detect that the websites were fake as they lacked the subject knowledge and/or did not know how to check for the credibility of information on the Internet. Teachers' poor subject knowledge has been well documented by South African educational researchers such as Morrow (2007), Taylor (2007, 2010), and Hoadley and Ward (2008).

By the end of the course, $48 \%$ of participants used websites either as teachers' resources and/or learners. The Afrikaans website Mieliestronk (www.mieliestronk.co. za) was a favourite. Ideally, all school librarians should be comfortable using the web (LIS Transformation Charter 2014), but one course may not be ensough to persuade educators to change their information behaviour.

\section{Conclusion}

Reflecting on practice is the sign of a good teacher. As this was the first time that participants tried out this new "method" of teaching research projects, mistakes were bound to be made and there is always room for improvement. Teacher \#1 said that the next year she would allow her learners to do group work which she personally dislikes. She would also provide them with note cards and spend more time teaching them note-taking. Teacher \#10 would concentrate more on reading techniques. Learners needed much more practice in creating a bibliography (\#4 and \#10). Teacher \#29 aimed to continue to improve the way she asked questions so that learners can think instead of just copying and pasting. For teacher \#24 who lacked confidence in the beginning, using older learners to assist her in the computer laboratory, she insisted she would do better next time as she has gained confidence.

Research question one asked how teachers understand information literacy education. For the vast majority of the participants who themselves had never written a research essay or conducted research, the information literacy phenomenon was brand new. Their own initial information literacy is brought into question as searching for information online was a daunting experience for them. By the time they are implementing the project with learners, at least $14(48 \%)$ participants are actively using the web. Besides their own cognitive limitations, the participants are also faced with major challenges: limited-to-no access to school libraries; low reading levels; most learners being from indigent homes; resources not being available in the home language of the learners; and school environments not conducive to radical pedagogical change. Given the many obstacles in their paths, it is surprising that the vast majority of participants express a fairly sound understanding of information literacy education by the end of the journal exercise.

Research question two asked how they make their information literacy explicit in the classroom. There is evidence that 15 or $52 \%$ of participants relate in their journals the information literacy skills which they are actively teaching their learners. Other ways that they "operationalise" their information literacy is to ensure learners have access to a wide variety of information sources. While many teachers may understand information literacy education, fewer are able to mediate it in the classroom.

The final question asked at what level is teachers' web knowledge and skills? Not only were their Internet search skills poor in the beginning, but also their computer literacy skills seemed rusty. By offering them the Weblinks Research database as a scaffold, teachers gained confidence in locating quality educational web resources. Although the number of teachers (48\%) using the web increased by the end of the course, many still struggled to evaluate web content.

Using journal writing as one piece of evidence in the argument for teachers' competency in teaching information literacy has proven rewarding in terms of the insights they illuminate. The journal documents their steep journey from learning theoretically about information literacy to applying it in the classroom. Keeping a journal is not for everyone. The writing ranged from sparse checklists to comprehensive, introspective records. As a whole, the journals provide invaluable temporal accounts of teachers' experiences. The words of one astute participant lend credence to the information literacy education course: She (participant \#1) remarks: "I expected to be taught how to be a librarian. I never imagined it would help me improve my teaching!"

\section{Recommendations}

The following three recommendations for further study are proposed: 
- A study examining teacher education programmes could provide up-to-date perspectives of whether or not the programmes include information literacy education.

- The teachers in the study seemed genuinely ignorant of many aspects of plagiarism. The fact that some teachers, after being exposed to the course, failed to submit a bibliography and more than half did not expect learners to provide a bibliography with their project warrants further research into the ethics of information use in the school environment.

- One of the reasons for the rollout of computer laboratories in the Western Cape was to improve the literacy and numeracy levels amongst learners. While some studies have been completed on the effect of technology on literacy and numeracy scores, new research should extend to include the effect of ICTs on learners' information literacy.

\section{References}

Alberta Learning. 2004. Focus on Inquiry: A Teacher's Guide to Implementing Inquiry-Based Learning. Edmonton, Alberta: Alberta Learning and Teaching Resources Branch. Accessed April 12, 2005. http://www.learning.gov.ab.ca/k_12/curricu lum/bySubject/focusoninquiry.pdf.

Association of College and Research Libraries (ACRL). 2002. Information Literacy Competency Standards for Higher Education. Chicago, IL: ALA. Accessed May 20, 2007. http://www.ala.org/ acrl/standards/informationliteracycompetency.

Asselin, M. 2003. "School Libraries in Pre-Service Teacher Education: A Research Program Examining the Inclusion of School Libraries and Information Literacy in Pre-Service Teacher Education From National and International Perspectives." In IASL Reports 2003: School Libraries Breaking Down Barriers. Selected Papers From the 32nd Annual Conference of the International Association of School Librarianship and the 7th International Forum on Research in School Librarianship. Durban, South Africa, 7-11 July 2003, edited by S. Zinn, G. Hart and E. Howe, 13-22. Seattle, WA: International Association of School Librarianship.

Asselin, M., A. Kymes, and V. Lam. 2007. "A Critical Examination of Information Literacy Instruction During a Grade 9 Research Project." Simile 7 (4):1-18.

Baxen, J., and L. Green. 1998. "Primary Teachers' Use of Learning Materials.” Accessed August 10, 2010. http://www.jet.org.za.

Boekhorst, A. K., and J. J. Britz. 2004. "Information Literacy at School Level: A Comparative Study Between the Netherlands and South Africa." South African Journal of Libraries and Information Science 70 (2):63-71.

Bruce, C. 2002. "Information Literacy as a Catalyst for Educational Change: A Background Paper." White paper prepared for UNESCO, the U.S. National Commission on Libraries and
Information Science, and the National Forum on Information Literacy, for use at the Information Literacy Meeting of Experts, Prague, The Czech Republic. Accessed June 11, 2009. http://eprints.qut.edu.au/4977/1/4977_1.pdf.

Czerniewicz, L. 1999. Information Literacy in Schools in the Western Cape: A Preliminary Study: A Report Prepared for the INFOLIT Project of the Adamastor Trust. Rondebosch, Cape Town: Adamastor Trust.

Czerniewicz, L., and C. Brown. 2005. "Access to ICTs for Teaching and Learning - From Single Artifact to Inter-Related Resources." International Journal of Education and Development Using ICT 1 (2). Accessed November 22, 2007. http://ijedict.dec.uwi.edu/viewarticle. php?id=38.

De Jager, K., M. Nassimbeni, and P. Underwood. 2007. "Libraries, Literacies and Learning: Retrospect and Prospects." In Libraries for the Future: Progress and Development of South African Libraries, edited by T. Bothma, P. Underwood and P. Ngulube, 133-48. Pretoria: Library and Information Association of South Africa and International Federation of Library Associations and Institutions.

Eidse, N., and S. Turner. 2014. "Doing Resistance Their Own Way: Counter-Narratives of Street Vending in Hanoi, Vietnam Through Solicited Journaling." Area 46 (3):242-8.

Equal Education (South Africa). 2011. We Can't Afford Not To: Costing the Provision of Functional School Libraries in South African Public Schools. Khayelitsha, South Africa: Equal Education. Accessed July 20, 2011. http://www.equaleducation.org.za/ sites/default/files/EqualEducationCostingBooklet.pdf.

Fiske, E. B., and H. F. Ladd. 2004. Elusive Equity. Washington, DC: Brookings Institution Press.

Gardner, H. 1999. Intelligence Reframed. Multiple Intelligences for the $21^{\text {st }}$ Century. New York: Basic Books.

Hart, G. 1999. "Project Work as a Vehicle for Information Literacy Education in Disadvantaged Schools: An Ethnographic Field Study of Grade Seven Project Work in a Primary School in Cape Town." M.LIS, University of Cape Town.

Hart, G. 2005. "The Readiness of Public Libraries in South Africa for Information Literacy Education: The Case of Mpumalanga Province." PhD dissertation. University of Cape Town.

Hart, G. 2011. "The "Tricky Business" of Dual-Use School Community Libraries: A Case Study in Rural South Africa." Libri 61:211-25.

Hayman, B., L. Wilkes, and D. Jackson. 2012. “Journaling: Identification of Challenges and Reflection on Strategies." Nurse Researcher 19 (3):27-31.

Henri, J. 2001. "Thinking and Informing: A Reality Check on Class Teachers and Teacher Librarians." In Proceedings of the Fifth International Forum on Research in School Librarianship \& 30th Annual Conference of the IASL. Auckland, New Zealand, 9-12 July, 2001, edited by P. Hughes and L. Selby, 119-28. Seattle, WA: International Association of School Librarianship.

Herring, J. 2007. 'A Critical Investigation of Students' and Teachers' Views of the Use of Information Literacy Skills in School Assignments." Accessed July 27, 2010. http://www.ala.org/ ala/mgrps/divs/aasl/aaslpubsandjournals/slmrb/slmrcon tents/volume9/informationliteracy.cfm. 
Hoadley, U., and C. L. Ward. 2008. Managing to Learn: Instructional Leadership in South African Secondary Schools. Cape Town: HSRC Press. Accessed April 7, 2009. http://www.hsrcpress.ac.za.

Hubbs, D. L., and C. F. Brand. 2005. "The Paper Mirror: Understanding Reflective Journaling." Journal of Experiential Education 28 (1):60-71.

International Federation of Library Associations and Institutions (IFLA). 2015. IFLA School Library Guidelines, 2nd revised ed. Edited by B. Schultz-Jones and D. Oberg, with contributions from the International Association of School Librarianship Executive Board. The Hague: International Federation of Library Associations and Institutions.

Jansen, J., and N. Taylor. 2003. "Educational Change in South Africa 1994-2003: Case Studies in Large-Scale Education Reform." Accessed March 4, 2009. http://www.jet.org.za/publications/ research/Jansen and Taylor_World Bank report.pdf.

King, L. 2007. "Information Literacy of Incoming Undergraduate Arts Students at the University of The Western Cape: Assessment of Competencies and Proficiencies." PhD dissertation, University of the Western Cape. Accessed July 12, 2008. http://etd.uwc.ac.za/.

Kuhlthau, C. 2004. Seeking Meaning: A Process Approach to Library and Information Services, 2nd ed. Westport, CT: Libraries Unlimited.

Kuhlthau, C., L. Maniotes, and A. Caspari. 2007. Guided Inquiry: Learning in the $21^{\text {st }}$ Century. Westport, CT: Libraries Unlimited.

Library and Information Association of South Africa (LIASA). 2004. Information Literacy Guidelines: Grades $R-12$. Pretoria: LIASA.

The Library and Information Services (LIS) Transformation Charter. 2014. Pretoria: Department of Arts and Culture and National Council for Library and Information Services. Accessed December 6, 2014. http://www.nlsa.ac.za/Downloads_01/ 2014_Final_LIS_Transformation_Charter.pdf.

Loertscher, D. 1996. “All That Glitters May Not Be Gold.” Emergency Librarian 24 (2):20-21, 23-25.

Maepa, E., and R. Mhinga. 2003. "Integrating a Community Library into the Teaching and Learning Programme of Local Schools: Experiences from Seshego Community Library, South Africa." In IASL Reports 2003: School Libraries Breaking Down Barriers. Selected Papers From the 32nd Annual Conference of the International Association of School Librarianship and the 7th International Forum on Research in School Librarianship. Durban, South Africa, 7-11 July 2003, edited by S. Zinn, G. Hart and E. Howe, 270-9. Seattle: International Association of School Librarianship.

McKenzie, J. 1999. Beyond Technology: Questioning, Research and the Information Literate School. Bellingham, WA: Fromnowon Press.

Merchant, L., and M. Hepworth. 2002. "Information Literacy of Teachers and Pupils in Secondary Schools." Journal of Librarianship and Information Science 34 (2):81-9.

Meth, P. 2003. "Entries and Omissions: Using Solicited Diaries in Geographical Research.” Area 35 (2):195-205.

Moore, P. 1998. Teaching Information Problem Solving in Primary Schools. Auckland: Open Polytechnic of New Zealand.

Moore, P. 2002. "An Analysis of Information Literacy Education Worldwide." White Paper prepared for UNESCO, the U.S. National Commission on Libraries and Information Science, and the National Forum on Information Literacy, for use at the Information Literacy Meeting of Experts, Prague, The Czech Republic, September 20-23, 2003. Accessed July 4, 2003. http://portal.unesco.org/ci/en/file_download.php/
33e3dd652a107b3be6d64fd67ae898f5Information+

Literacy+Education+\%28Moore\%29.pdf.

Morrow, W. 2007. Learning to Teach in South Africa. Cape Town: HSRC Press. Accessed July 25, 2007. http://hsrcpress.ac.za.

Olën, S. 1994. "The School Media Centre in the Curricular for Initial Teachers' Training." D.Bibl. dissertation, University of South Africa.

Probert, E. 2009. "Information Literacy Skills: Teacher Understandings and Practice." Computers and Education 53:24-33.

Slyfield, H. 2001. "Information Literacy in New Zealand Secondary and Primary Schools." In Proceedings of the Fifth International Forum on Research in School Librarianship \& 30th Annual Conference of the IASL. Auckland, New Zealand, 9-12 July, 2001, edited by P. Hughes and L. Selby, 162-81. Seattle, WA: International Association of School Librarianship.

Small, R. V., and M. P. Arnone. 2000. Turning Kids on to Research. Englewood, CO: Libraries Unlimited.

South Africa. 2002. Revised National Curriculum Statement, June 2002. Pretoria: Department of Education. Accessed December 12, 2006. http://www.education.gov.za/LinkClick.aspx?file ticket=WJoXaOgvys4\%3D\&tabid $=266 \& \mathrm{mid}=720$.

South Africa. 2004. White Paper on e-Education: Transforming Learning and Teaching Through Information and Communication Technologies. Pretoria: Department of Education. Accessed May 23, 2005. http://www.education.gov. za/LinkClick.aspx?fileticket=\%2BfGxKN\%2FCtg0\%3D.

South Africa. 2009. "Review of the Implementation of the National Curriculum Statement: Final Report.” Accessed August 1, 2011. http://www.education.gov.za.

South Africa. 2011a. Curriculum and Assessment Policy Statement (CAPS): Computer Applications Technology (CAT). Pretoria: Department of Basic Education. Accessed September 18, 2011. http://www.education.gov.za.

South Africa. 2011b. Report on the Annual National Assessments (ANA) of 2011. Pretoria: Department of Basic Education. Accessed July 14, 2011. http://www.education.gov.za.

South Africa. 2014a. NEIMS Standard Reports October 2014. Pretoria: Department of Basic Education. Accessed November 4, 2014. http://www.education.gov.za.

South Africa. 2014b. Report on the Annual National Assessment of 2014. Pretoria: Department of Basic Education. Accessed October 30, 2015. http://www.education.gov.za.

South Africa. 2014c. School Realities 2014. Pretoria: Department of Basic Education. Accessed August 12, 2015. http://www.education.gov.za.

South African Human Rights Commission, and Public Hearing on the Right to Basic Education. 2006. "Report of the public hearing on the right to basic education: 12-14 October 2005." Accessed January 12, 2009. http://www.sahrc.org.za/home/21/files/ Reports/Right to basic education 2006.pdf.

Spalding, E., and A. Wilson. 2002. "Demystifying Reflection: A Study of Pedagogical Strategies That Encourage Reflective Journal Writing." Teachers College Record 104 (7):1393-421.

Spaull, N. 2012. Poverty and Privilege: Primary School Inequality in South Africa. Stellenbosch Economic Working Papers 13/12. Stellenbosch: University of Stellenbosch, Department of Economics.

Statistics South Africa. 2011. Mid-Year Population Estimates. Pretoria: Statistics South Africa. Accessed July 29, 2011. http://www.stassa.gov.za/publications/P0302/P03022011.pdf. Taylor, N. 2007. "Equity, Efficiency and the Development of South African Schools." In International Handbook of School 
Effectiveness and Improvement, edited by T. Townsend. Dordrecht, NL: Springer. Accessed August 10, 2010. http://www.jet.org.za.

Taylor, N. 2010. "Patronage kills Education”. The Times, March 2, 2010. Accessed August 10, 2010. http://www.jet.org.za.

Taylor, N., B. Fleisch, and J. Schindler. 2008. "Changes in Education Since 1994. Study Commissioned by the Policy Unit of the Office of the Presidency." Accessed July 7, 2009. http://www.jet.org.za.

Walker, C. 2001. "Information Literacy: How Low Do We Go?" Mousaion 19 (2):61-72.

Western Cape (South Africa). 2007. The Quality of Teaching and Learning and Educator Development. Cape Town, South Africa: Western Cape Education Department. Unpublished.

Williams, D., and C. Wavell. 2006. "Information Literacy in the Classroom: Secondary School Teachers' Conceptions." Research Report 15, Department of Information Management, Aberdeen Business School, The Robert Gordon University. Accessed August 17, 2008. https://openair.rgu.ac.uk/handle/ $10059 / 42$.
Zinn, S. 1997. "Integrating information skills into the curriculum: an action research investigation at an ex-House of Representatives high school." M. Bibl. dissertation, University of the Western Cape. Accessed May 25, 2004. http://etd.uwc.ac.za.

Zinn, S. 2008. Report: ACE School Librarianship, Information Literacy Education Course, Port Elizabeth, 7-11 January 2008. Bellville: UWC, Department of Library and Information Science. Unpublished.

Zinn, S. 2013. "The Information Literacy Self-Efficacy of Disadvantaged Teachers in South Africa." In Worldwide Commonalities and Challenges in Information Literacy Research and Practice, edited by S. Kurbanoğlu, E. Grassian, D. Mizrachi, R. Catts, and S. Špiranec, 212-18. European Conference on Information Literacy, Istanbul, Turkey, 22-25 October 2013. Revised Selected Papers. Series Communications in Computer and Information Science, 397. Cham, Switzerland: Springer. doi: http://link.springer.com/chapter/ 10.1007\%2F978-3-319-03919-0_27. 